\title{
Glucose-6 Phosphate Dehydrogenase Deficiency in terms of hemolysis indicators and management
}

$\begin{array}{ll}\text { Hayder H. Al-Momen* } & \text { FICP } \\ \text { Muthanna F. Athab** } & \text { FICP } \\ \text { Anwer S. Al-Zubaidi** } & \text { FICP }\end{array}$

Abstract:

Background: Glucose-6 Phosphate Dehydrogenase (G6PD) Deficiency is one of the commonest inherited enzyme abnormalities in humans, caused by many mutations that reduce the stability of the enzyme and its level as red cells progress in age.

Fac Med Baghdad 2017; Vol.59, No.2 Received: Mar. 2017 Accepted: May .2017
Objectives: To determine the useful hematologic indicators of hemolysis, observe an early detection of G6PD enzyme deficiency (if any), and the available therapeutic measures.

Patients and Methods: 123 patients with G6PD deficiency and hemolysis after exposure to fava beans whom visited AL-Elwiya Pediatric Teaching Hospital from the $1^{\text {st }}$ of February 2016 till $31^{\text {st }}$ of May 2016 were entered this study retrospectively. Hemolysis laboratory indicators were observed. Management supportive measures were put in consideration also.

Results: We found that 10-20\% levels of hematocrit and normochromic normocytic anemia were the most frequent on presentation, while a range of 15.1-20\% of reticulocyte counts was the most common with lower rates in females group. Hyperbilirubinemia was seen with nil patients had abnormal renal function tests. About three quarters $(76.4 \%$ ) of the total number of involved cases had glucose-6-phosphate dehydrogenase (G6PD) deficiency.

Only 4 patients required no blood transfusion, 102 patients $(82.9 \%)$ needed transfusion once, and the rest $17(13.8 \%)$ had more than one blood transfusion. Most of cases $(91.1 \%)$ recovered within the first 3 days. However; all cases were recovered by the fourth day of admission.

Conclusion: Hemoglobin and blood morphology with hyperbilirubinemia were useful hematologic indicators of hemolytic process, while blood transfusion was the most used therapeutic measure, and recovery was expected within 2-3 days.

Key words: G6PD enzyme, hemolysis, blood transfusion, and therapeutic measures.

\section{Introduction:}

Glucose-6-phosphate dehydrogenase (G6PD)
deficiency is a common genetic abnormality known to
predispose to acute hemolytic anemia (AHA), which
can be triggered by certain drugs or infection. However,
the commonest trigger is fava beans (Vicia faba)
ingestion, causing AHA (favism), which may be life-
threatening especially in children. (1) A clinical
symptom of G6PD deficiency closely linked to drug
induced haemolysis is the hemolytic anemia resulting
from the ingestion of the fava bean. (2,3)
Patients with favism are always G6PD deficient, but not
all G6PD deficient in- dividuals develop haemolysis
when they ingest fava beans. It is assumed that some
other factors, such as genetic and metabolism of the
active ingredients in the beans, which causes oxidative
damage in red blood cells, are involved. (3) During the
second half of the twentieth century, severe hemolytic
anemia in individuals
* Dept. of Pediatrics/ University of Baghdad/Al-Kindy
College of Medicine haider77hadi@yahoo.com,
**Pediatrics specialist, Al-Elwiya Pediatrics Teaching
Hospital.

ingesting fava beans, more commonly in children, was reported. (4)

In Mediterranean area, the major type of allele that exists is called the "Mediterranean" variant, among the population, whereas in other countries such as Japan there is a different variant with a different type of mutation prevalent within that population. This type of mutation is called the "Japan" variant. The Mediterranean variant, found in Southern Europe, the Middle East and in India, is characterized by very low enzyme activity (0-10\%) in RBCs using spectrophotometric and potentiometric methods. (5)

Deficiency of glucose-6-phosphate dehydrogenase (G6PD), an X-linked recessive enzymatic defect in the hexose monophosphate shunt that protects cellular damage from oxidative stress, is a common haematological problem worldwide. (6)

At a public health level, preventive measures may be useful. Subjects with G6PD deficiency may not even know which fava beans are until they collapse with favism. (7)

Nevertheless; ingestion of fava beans, certain drugs, infections, and metabolic conditions can cause 
hemolysis. Inadequate management of those G6PDdeficient individuals who develop acute hemolytic anemia can lead to permanent neurologic damage or death. $(8,9)$

Number of factors can precipitate hemolysis in G6PDdeficient subjects; such as certain drugs, infections, and some metabolic conditions, like diabetic ketoacidosis. (10-17)

Clinical signs and symptoms of hemolysis typically arise within 24 to 72 hours of drug dosing, and anemia worsens until about day (7). This makes it difficult for the health practitioner to identify a hemolytic crisis in patients who undergo outpatient or short hospital stay (less than 24 hour) procedures. Therefore, the practitioner should inform the high-risk patient and his or her caretaker to look for signs and symptoms of a hemolytic crisis (headache, dyspnea, fatigue, lumbar/substernal pain, jaundice, scleral icterus, and dark urine). (4)

Treatment consists of discontinuation of the offending agent and maintenance of urine output by infusion of crystalloid solutions and diuretics such as mannitol and/or furesomide, with blood transfusion when needed. $(4,18)$

Also, treatment of hyperbilirubinemia in G6PDdeficient neonates, when indicated, is with phototherapy and exchange transfusions. Prophylactic oral phenobarbital does not decrease the need for phototherapy or exchange transfusions in G6PDdeficient neonates. $(19,20)$

\section{Aim of the study:}

To determine the useful hematologic indicators of hemolysis, observe an early detection of G6PD enzyme deficiency (if any), and the available therapeutic measures.

\section{Patients and Methods:}

Cases with history of fava beans ingestion reaching the emergency room of AL-Elwiya Pediatric Teaching Hospital during the period from the $1^{\text {st }}$ of February 2016 till $31^{\text {st }}$ of May 2016 were targeted retrospectively in this study, and their total number was 238 patients.

The important investigations tracked from medical records includes: complete blood count with blood film and Reticulocyte count, direct Coomb's test, renal function tests, serum bilirubin (total and fractionated), as well as general urine examination (with urobilinogen) and G6PD enzyme assay screening test.

Supportive measures in the form of intravenous fluids with or without blood transfusion were recorded from hospital files.

Only fully recovered patients whom discharged in a good condition were allowed to enter this study.

Any file of any patient that did not contain any of the above information was excluded.
Because of that; only 123 patients were involved out of 238,101 of them were males and 22 were females.

All of them were between 1-13 years old at time of diagnosis.

Z-test to measure P-value was used for statistical evaluations.

\section{Results:}

Investigations:

A. Hematocrit level (PCV):

The most frequent range of hematocrit levels that our patients got on presentation at the hospital was $10-20 \%$, while less than $10 \%$ levels became next in frequency, as shown in Figure 1.

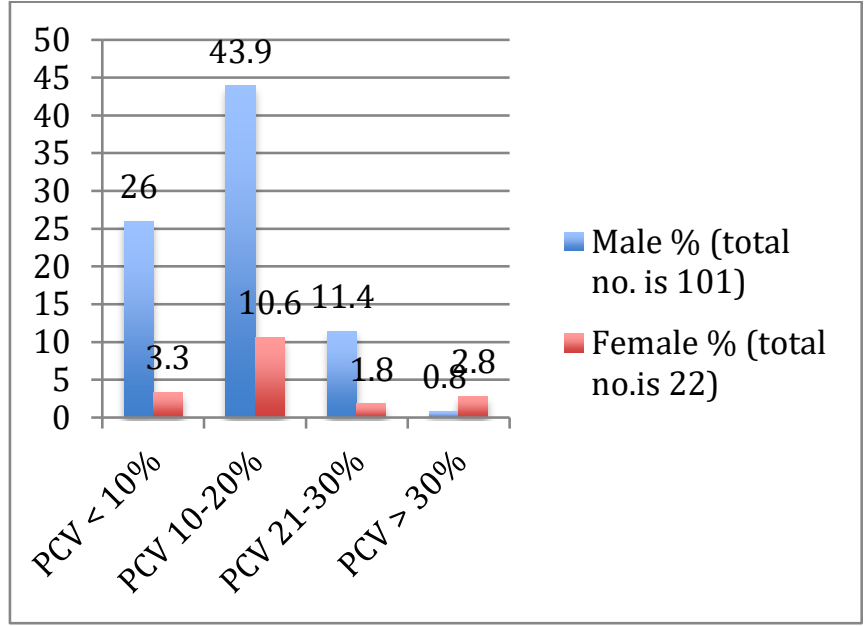

Figure 1 The range of hematocrit levels (during their first presentation at emergency department)

Doing simple calculations based on figure (1) and results, we have 86 male patients $(69.9 \%)$ out of the total (123 patients) whom had hematocrit levels $\leq 20 \%$, compared to 17 females (13.9\%).

Z-test between 2 proportions $=3.54 \rightarrow \mathrm{P}$-value $=0.022$. B. Type of anemia: Most of patients had normochromic normocytic anemia (118 patients; 95.9\%) and only 5 patients $(4.1 \%)$ had hypochromic microcytic red blood cells (1 male and 4 females). Nevertheles; 100 males $(81.3 \%)$ out of the total (123 patients) had mean cell volume (MCV) levels $>70$ femtoliter (fl) compared to 18 females (14.6\%), which was the cut-line for microcytic red blood cells, while a level of mean cell hemoglobin concentation (MCH) less than 27 picogram (pg) was considered as hypochromic red blood cells. 


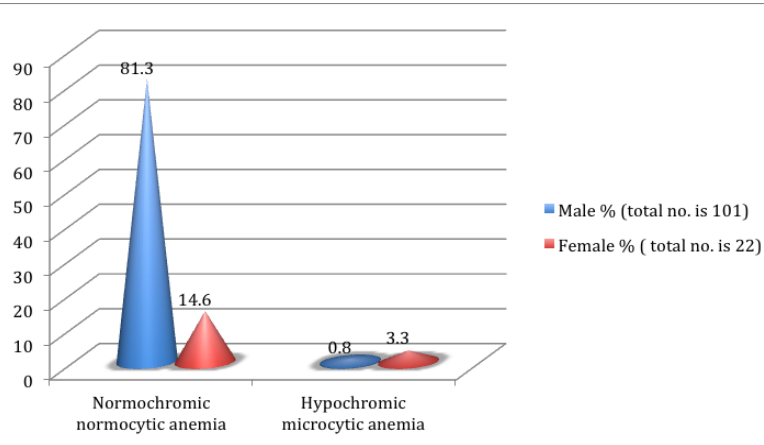

Figure 2 shows all that pecentages.

Z-test between 2 proportions $=3.23 \rightarrow \mathrm{P}$-value $=0.0223$

Table 1 with a similar trend in case of reticulocyte production index (RPI)(21). A value of 2-3 (of RPI) was the most frequent in both sex groups with a high

Table 1 The reticulocyte count (\%) and reticulocyte production index (RPI)

\begin{tabular}{|c|c|c|c|c|c|c|}
\hline \multirow{2}{*}{ Reticulocyte count (\%) } & \multicolumn{2}{|l|}{ Total } & \multicolumn{2}{|l|}{ Male } & \multicolumn{2}{|l|}{ Female } \\
\hline & No. of patients & $\%$ & No. of patients & $\%$ & No. of patients & $\%$ \\
\hline $2-6$ & 19 & 15.4 & 9 & 7.3 & 10 & 8.1 \\
\hline $6.1-10$ & 26 & 21.1 & 16 & 13.1 & 10 & 8.1 \\
\hline $10.1-15$ & 25 & 20.3 & 23 & 18.7 & 2 & 1.6 \\
\hline $15.1-20$ & 30 & 24.4 & 30 & 24.4 & 0 & 0 \\
\hline$>20$ & 23 & 18.7 & 23 & 18.7 & 0 & 0 \\
\hline \multirow[t]{2}{*}{ RPI } & Total & & Male & & Female & \\
\hline & No. of patients & $\%$ & No. of patients & $\%$ & No. of patients & $\%$ \\
\hline$<2$ & 13 & 10.6 & 10 & 8.1 & 3 & 2.4 \\
\hline $2-3$ & 80 & 65 & 61 & 49.6 & 19 & 15.5 \\
\hline 3 & 30 & 24.4 & 30 & 24.4 & 0 & 0 \\
\hline
\end{tabular}

$R P I=$ reticulocyte $\% \times \frac{\text { observed hemoglobin }}{\text { normal hemoglobin }} \times 0.5$, where normal hemoglobin $(\mathrm{Hb})=12 \mathrm{~g} \mid \mathrm{dl}$.

D. The shape of the erythrocytes:

Blister cells appeared in most of blood films in both sexes, this is clarified in Figure 3.

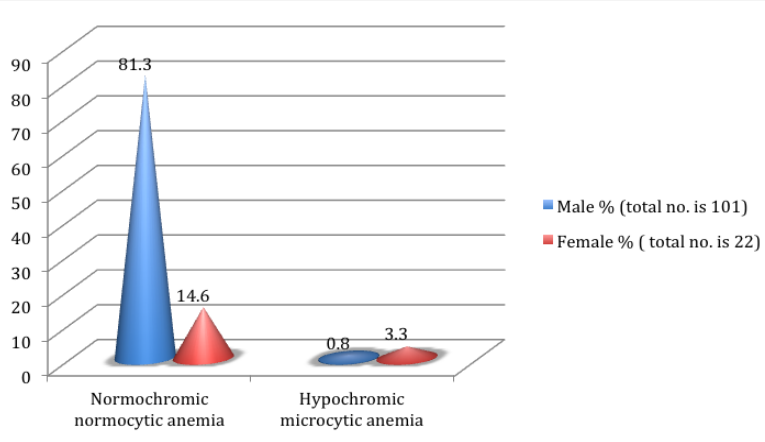

Figure 2 The types of presenting anemia associated with favism

C. Reticulocyte count \&RPI (reticulocyte production index): We found generally that reticulocyte counts (\%) of $15.1-20 \%$ were most common, but females favoured lower counts inside their group, as illustrated in

percentage of $65 \%$ of total no. of patients $(49.6 \%$ males and $15.5 \%$ females).
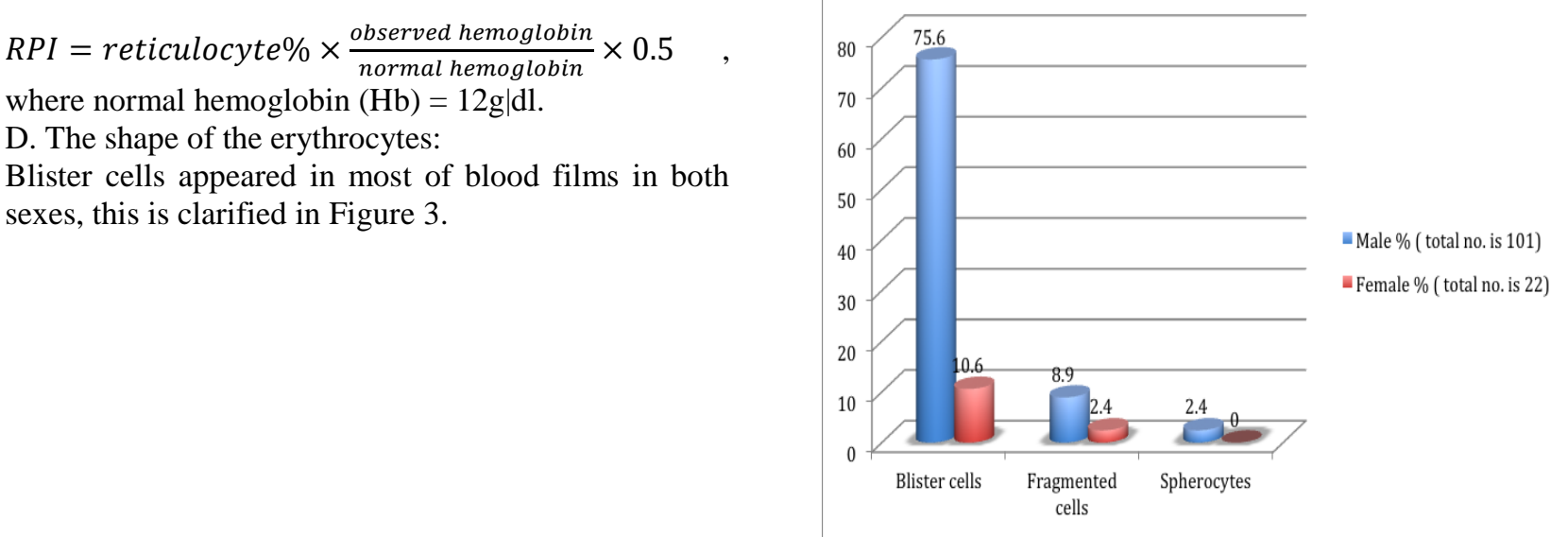

Figure 3 Distribution of various shapes of red blood cells (RBCs) in favism 
E. Serum bilirubin level: Hyperbilirubinemia was found in all patients, which is considered a usual result

of hemolysis with the highest readings of 25-30 $\mathrm{mmol} / \mathrm{L}$, as seen in

Table 2 .

F. Blood urea nitrogen and serum creatinine: Renal function (blood urea nitrogen and serum creatinine) was normal in all patients $(100 \%)$, and so the function was not significantly impaired.

Table 2 Range of total serum bilirubin

\begin{tabular}{|c|c|c|c|c|c|c|}
\hline \multirow{2}{*}{$\begin{array}{l}\text { Total } \\
\text { serum } \\
\text { bilirubin } \\
\mathrm{mmol} / \mathrm{L}\end{array}$} & \multicolumn{2}{|l|}{ Total } & \multicolumn{2}{|l|}{ Male } & \multicolumn{2}{|l|}{ Female } \\
\hline & $\begin{array}{l}\text { No. of } \\
\text { patients }\end{array}$ & $\%$ & $\begin{array}{l}\text { No. of } \\
\text { patients }\end{array}$ & $\%$ & $\begin{array}{l}\text { No. of } \\
\text { patients }\end{array}$ & $\%$ \\
\hline $\begin{array}{l}25-50 \\
(>1.5-3 \\
\mathrm{mg} / \mathrm{dl})\end{array}$ & 52 & 42.3 & 44 & 35.8 & 8 & 6.5 \\
\hline $\begin{array}{l}51-100 \\
(3.1-6 \\
\mathrm{mg} / \mathrm{dl})\end{array}$ & 49 & 39.8 & 41 & 33.3 & 8 & 6.5 \\
\hline $\begin{array}{l}101-200 \\
(6.1-12 \\
\mathrm{mg} / \mathrm{dl})\end{array}$ & 21 & 17.1 & 16 & 13 & 5 & 4.1 \\
\hline $\begin{array}{l}>200 \\
(>12 \\
\mathrm{mg} / \mathrm{dl})\end{array}$ & 1 & 0.8 & 0 & 0 & 1 & 0.8 \\
\hline
\end{tabular}

G. G6PD enzyme assay: The deficiency was screened through de-coloration of methylene blue.

Around 94 patients (76.4\%) out of the total cases had deficient G6PD enzyme; most of them were males (90 patients) that stands for $(73.4 \%)$ compared to 4 female patients, which represents $(3.3 \%)$. This is obvious in Figure 4.

Z-test between 2 proportions $=2.56 \rightarrow \mathrm{P}$-value $=0.02$.

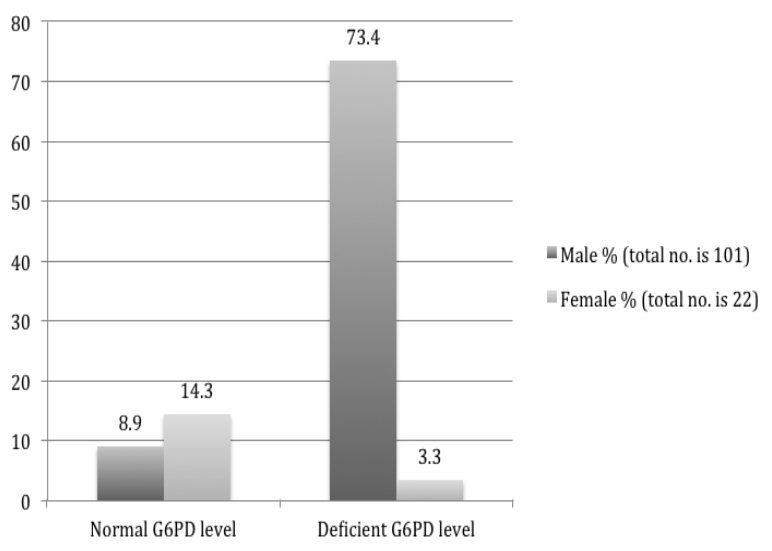

Figure 4 G6PD enzyme

Treatment: Nearly all patients required blood transfusion, only 4 of them were considered with no need to blood as per the opinion of treating physician, also some patients required more than one time of blood transfusions as shown in Table 3.

This might be due to continuous hemolysis even with high initial hemoglobin levels.

Recovery: It was dependent on regaining normal hematocrit levels (around 30\%) for at least 12-24 hours. As it is stated in table 4 below, all of the cases (100\%) recovered from the disease within the $1^{\text {st }} 4$ days, and $(91.1 \%)$ recovered within the $1^{\text {st }} 3$ days.

Table 3 Treatment regimen used

\begin{tabular}{|c|c|c|c|c|c|c|}
\hline \multirow[b]{2}{*}{$\begin{array}{l}\text { TREATME } \\
\text { NT }\end{array}$} & \multicolumn{2}{|l|}{ Total } & \multicolumn{2}{|l|}{ Male } & \multicolumn{2}{|l|}{ Female } \\
\hline & $\begin{array}{l}\text { No. of } \\
\text { patient } \\
\text { s }\end{array}$ & $\%$ & $\begin{array}{l}\text { No. of } \\
\text { patient } \\
\text { s }\end{array}$ & $\%$ & $\begin{array}{l}\text { No. of } \\
\text { patient } \\
\text { s }\end{array}$ & $\%$ \\
\hline $\begin{array}{l}\text { Blood } \\
\text { transfusion } \\
\text { (once) }\end{array}$ & 102 & $\begin{array}{l}82 . \\
9\end{array}$ & 83 & $\begin{array}{l}67 . \\
5\end{array}$ & 19 & $\begin{array}{l}15 . \\
5\end{array}$ \\
\hline $\begin{array}{l}\text { Blood } \\
\text { transfusion } \\
(>\text { one time) }\end{array}$ & 17 & $\begin{array}{l}13 . \\
8\end{array}$ & 17 & $\begin{array}{l}13 . \\
8\end{array}$ & 0 & 0 \\
\hline $\begin{array}{l}\text { NO Blood } \\
\text { transfusion }\end{array}$ & 4 & 3.3 & 1 & 0.8 & 3 & 2.4 \\
\hline $\begin{array}{l}\text { Intravenous } \\
\text { Fluid } \\
\text { transfusion }\end{array}$ & 123 & 100 & 101 & $\begin{array}{l}82 . \\
1\end{array}$ & 22 & $\begin{array}{l}17 . \\
9\end{array}$ \\
\hline
\end{tabular}

Table 4 Duration of stay in the hospital

\begin{tabular}{llllllll} 
& \multicolumn{2}{l}{ Total } & \multicolumn{3}{c}{ Male } & \multicolumn{3}{c}{ Female } \\
\cline { 2 - 7 } (days) & $\begin{array}{l}\text { No. of } \\
\text { patients }\end{array}$ & $\%$ & $\begin{array}{l}\text { No. of } \\
\text { patients }\end{array}$ & $\%$ & $\begin{array}{l}\text { No. of } \\
\text { patients }\end{array}$ & $\%$ \\
\hline 1 & 26 & 21.2 & 19 & 15.4 & 7 & 5.7 \\
\hline 2 & 33 & 26.8 & 21 & 17.1 & 12 & 9.8 \\
\hline 3 & 53 & 43.1 & 50 & 40.7 & 3 & 2.4 \\
\hline 4 & 11 & 8.9 & 11 & 8.9 & 0 & 0 \\
\hline
\end{tabular}

\section{Discussion:}

Hematocrit level was $\leq 20 \%$ in majority of cases ; this level may be nearly similar to the results of a study from Mosul (22), but lower than that mentioned by Segel GB. (23). This may give us a clue of a more lower hematocrit levels in Iraqi patients rather than western populations. In 118 cases $(95.9 \%)$, the anemia was of normochromic normocytic type, while the rest (5 cases) had hypochromic microcytic anemia. Nearly similar results were reported by Sawsan S. Abbas (24), NelsonDA (25), and ErbagclAB. (26) Reticulocyte count generally was high, precisely the RPI (Reticulocyte Production Index), which was between 2-3 in most of the involved cases; this indicates that hemolysis exceeded the ability of bone marrow to compensate, so the true reticulocyte count may be low for the first 3-4 days and this consistent with Hassan MK (27) and ErbagclAB. (26) 
Blister erythrocytes were seen in the blood film of most cases, followed by fragmented cells, and spherocytes in the last rank. Nearly similar picture was reported by Luzzatto L (28), Yilmaz N (29) and Frank JE. (30) Hyperbilirubinemia was found in all patients, which is considered as a usual result of hemolysis. (22) The peak level of total serum bilirubin was between 25-100 $\mathrm{mmol} / \mathrm{L}(>1.5-6 \mathrm{mg} / \mathrm{dl})$. This agrees with many other studies like those done by Omar SK (22), Sawsan S. Abbas (24), and Beutler E. (31) Renal function (blood urea nitrogen and serum creatinine) was normal in all patients (100\%), and clinically they were well. This is consistent with Belsy MA (32) and IbidS. (33) G6PD enzyme assay was done early in the first day of admission and showed early detection of deficient enzyme in 94 cases $(76.4 \%)$. This is consistent with other authors such as ErbagclAB (26), Abbas SS (34), Mehta A (35), and S ML. (36) Since most of patients had moderate to severe anemia, and continuous hemolytic process was suspected even with relatively mild anemia, 119 patients $(96.7 \%)$ were given blood transfusion as a major constituent of therapy. This relatively aggressive approach might point out to the severity of variant(s) existing in our locality, while only 4 cases $(3.3 \%)$ did not need blood transfusion. Approximate results were also reported by Omar SK (22), ErbagclAB (26) and S ML. (36) Finally, all patients recovered well. Recovery in most of them (91.1\%), was within the first 3 days. This period was also found by Frank JE.(30), IbidS (33), and Hilmi FA. (37)

\section{Conclusion:}

Hemoglobin and blood morphology with hyperbilirubinemia were useful hematologic indicators of hemolytic process, but renal function was not affected, especially in patients with early presentation followed by early treatment. A significant number of patients showed an early reduction of G6PD enzyme within the course of the disease. Blood transfusion was the most used therapeutic measure, and recovery was expected within 2-3 days.

\section{Author's contributions:}

Muthanna Falah Athab and Anwer Sabeeh Al-Zubaidi: data collection and interpretation.

Hayder Hadi Al-Momen: data analysis and critical revision

\section{References:}

1. Reading NS, Sirdah MM, Shubair ME, Nelson BE, Al-Kahlout MS, Al-Tayeb JM, et al. Favism, the commonest form of severe hemolytic anemia in Palestinian children, varies in severity with three different variants of G6PD deficiency within the same community. Blood Cells, Mol Dis. 2016;60:58-64.

2. Matsubara S, Takayama T, Iwasaki R, Komatsu N,
Matsubara D, Takizawa $T$, et al. Enzymecytochemically detectable glucose-6-phosphate dehydrogenase in human villous macrophages (Hofbauer cells). Placenta. 2001;22(10):882-5.

3. Cappellini MD, Martinez di Montemuros F, De Bellis G, Debernardi S, Dotti C, Fiorelli G. Multiple G6PD mutations are associated with a clinical and biochemical phenotype similar to that of G6PD Mediterranean. Blood [Internet]. 1996;87(9):3953-8. Available http://www.ncbi.nlm.nih.gov/pubmed/8611726

4. Cappellini MD, Fiorelli G. Glucose-6-phosphate dehydrogenase deficiency. Lancet. 2008;371(9606):64-74.

5. El-gezeiry D, El-gendy W, El-kaffash D, Hassab H. Comparative study for the detection of $563 \mathrm{C}$----T G6PD mutationusing restriction enzyme assay and amplification and refractory mutation system (ARMS). Alexandria J Pediatr. 2008; 19:51-5.

6. Anonymous. Glucose-6-phosphate dehydrogenase deficiency. WHO Working Group. Bull World Health Organ. 1989;67(6):601-11.

7. Luzzatto L, Nannelli C, Notaro R. Glucose-6Phosphate Dehydrogenase Deficiency. Vol. 30, Hematology/Oncology Clinics of North America. 2016. p. 373-93.

8. Beutler E. The molecular biology of G6PD variants and other red cell enzyme defects. Аnпи Rev Med. 1992;43:47-59.

9. Elyassi AR, Rowshan HH. Perioperative management of the glucose-6-phosphate dehydrogenase deficient patient: a review of literature. Anesth Prog [Internet]. 2009;56(3):86-91. Available from:

http://www.ncbi.nlm.nih.gov/pubmed/19769422\%5Cn http://www.pubmedcentral.nih.gov/articlerender.fcgi? artid $=$ PMC2749581

10. Beutler E. G6PD deficiency. Blood. 1994;84(11):3613-36.

11. Altikat S, Ciftci M, Buyukokuroglu ME. In vitro effects of some anesthetic drugs on enzymatic activity of human red blood cell glucose 6-phosphate dehydrogenase $\backslash r 758$. Pol J Pharmacol [Internet]. 2002;54(1):67-71. Available from: http://www.ncbi.nlm.nih.gov/pubmed/12020046

12. Ho H, Cheng M, Chiu DT. Glucose-6-phosphate dehydrogenase-from oxidative stress to cellular functions and degenerative diseases. Redox Rep [Internet]. 2007;12(3):109-18. Available from: http://www.ncbi.nlm.nih.gov/pubmed/17623517

13. Tabatabaei SM, Khorashad AS, Sakeni M, Raeisi A, Metanat Z. Prevalence of glucose-6-phosphate dehydrogenase (G6Pd) deficiency in Southeast Iran: Implications for malaria elimination. J Infect Dev Ctries. 2015;9(3):289-97.

14. Baehner RL, Nathan DG, Castle WB. Oxidant injury of caucasian glucose-6-phosphate dehydrogenase- 
deficient red blood cells by phagocytosing leukocytes during infection. J Clin Invest. 1971;50(12):2466-73.

15. Tanphaichitr VS, Suvatte V, Mahasandana $C$, Tuchinda S. Transient, acquired glucose-6-phosphate dehydrogenase deficiency in Thai children with typhoid fever. Southeast Asian J Trop Med Public Health. 1982;13:105-9.

16. Shannon K, Buchanan GR. Severe hemolytic anemia in black children with glucose-6-phosphate dehydrogenase deficiency. Pediatrics [Internet]. 1982;70(3):364-9. Available from: http://www.ncbi.nlm.nih.gov/entrez/query.fcgi? cmd $=R$ etrieve \&amp; $d b=$ PubMed\&amp;dopt=Citation \&amp; list_uids $=7110809$

17. Edwards CQ. Anemia and the liver hepatobiliary manifestations of anemia. Vol. 6, Clinics in Liver Disease. 2002. p. 891-907.

18. Domingo GJ, Satyagraha AW, Anvikar A, Baird K, Bancone $G$, Bansil P, et al. G6PD testing in support of treatment and elimination of malaria: recommendations for evaluation of G6PD tests. Malar J [Internet]. 2013;12(391):1-12. Available from: http://www.pubmedcentral.nih.gov/articlerender.fcgi? artid $=3830439 \&$ tool $=$ pmcentre $\&$ rendertype $=a b s t r a c$ $t$

19. Liu H, Liu W, Tang X, Wang T. Association Between G6PD Deficiency and Hyperbilirubinemia in Neonates: A Meta-Analysis. Pediatr Hematol Oncol. 2015;32:928.

20. Riskin A, Gery N, Kugelman A, Hemo M, Spevak I, Bader D. Glucose-6-phosphate dehydrogenase deficiency and borderline deficiency: Association with neonatal hyperbilirubinemia. J Pediatr. 2012;161(2).

21. Himelstein BP. Palliative care in pediatrics. Vol. 23, Anesthesiology Clinics of North America. 2005. p. 837-56.

22. Omar SK. "Clinical profile of children with favism." Ann Coll Med Mosul. 1998;1(2):27-31.

23. Segel GB. Enzymatic Defects. In: Behrman R.E., Kliegman R.M. JHB, editor. Nelson Textbook of Pediatrics, Philadelphia. 17th. WB Saunders; 2004. p. 1636-8.

24. Sawsan S. Abbas. "G6PD deficiency in a group of
Iraqi children." J Fac Med. 2003;47(1):9-11.

25. NelsonDA, DaveryFR. Erythrocytic disorders. In: $J B H$, editor. Clinical Diagnosis and Management by Laboratory Methods, Philadelphia. WB Saunders Co.; 2007. p. 660-2.

26. ErbagclAB. Erythrocyte Glucose-6-phosphate Dehydrogenase Deficiency Frequency in Gaziantep, Turkey. East J Med. 2002;7(1):8-15.

27. Hassan MK, Taha JY, Al-Naama LM, Widad NM, Jasim SN. Frequency of haemoglobinopathies and glucose-6-phosphate dehydrogenase deficiency in Basra. East Mediterr Heal J. 2003;9(1-2):45-54.

28. Luzzatto L. Glucose-6-phosphate Dehydrogenase Deficiency and Hemolytic Anemia. In: Nathan and Oski, editor. Hematology of Infancy and Childhood. sixth. Philadelphia: W.B.Saunders Company; 2003. p. 720-37.

29. Yilmaz N, AB E. Evaluation of Erythrocyte G6PD activity unit, it is better defined as a function of RBC count. Gaziantep Tip Derg. 2004;1(2):51-63.

30. Frank JE. Diagnosis and management of G6PD deficiency. Am Fam Physician. 2005;72(7):1277-82.

31. BeutlerE, VulliamyV, LuzzattoL. Hematologically important mutations: glucose-6-phosphate dehydrogenase. Blood cells Mol Dis. 2004;22:49-56.

32. Belsy MA. The Epidemiology of Favism. Bull Wld Hlth Org. 2004;48(4).

33. bidS. Favism: Clinical and Biochemical Data. J Med Gen. 2000;6:34-5.

34. Abbas SS. "G6PD screening in the newborn babies. " J Fac Med. 2003;45(3-4):205-6.

35. Mehta A, Mason PJ, Vulliamy TJ. Glucose-6phosphate dehydrogenase deficiency. Best Pract Res Clin Haematol. 2000;13(1):21-38.

36. S ML, Dacie. J. G6PD Screening. In: Dacie J, editor. Practical Haematology. 9th ed. Churchill Livingstone Co.; 2001. p. 435.

37. Hilmi FA, Al-Allwi NA, Rassam M, Al-Shamma G, Al-Hashimi A. Red cell glucose-6-phosphate dehydrogenase phenotypes in Iraq. East Mediterr Heal J. 2002;8(1):42-8. 